\title{
A Study of the Effect of Cyclosporine on Fevipiprant Pharmacokinetics and its Absolute Bioavailability Using an Intravenous Microdose Approach ${ }^{\llbracket}$
}

\author{
H. Markus Weiss, Ken-Ichi Umehara, Veit J. Erpenbeck, Meredith Cain, Janardhana Vemula, \\ Walid Elbast, and Markus Zollinger
}

Novartis Institutes for Biomedical Research, Basel, Switzerland; Novartis Healthcare Pvt. Ltd., India (J.V.)

Received February 4, 2020; accepted July 17, 2020

\begin{abstract}
This drug-drug interaction study determined the effect of cyclosporine, an inhibitor of organic anion transporting polypeptide (OATP) 1B3 and P-gp, on the pharmacokinetics (PK) of fevipiprant, an oral, highly selective, competitive antagonist of the prostaglandin $D_{2}$ receptor 2 and a substrate of the two transporters. The concomitant administration of an intravenous microdose of stable isotope-labeled fevipiprant provided the absolute bioavailability of fevipiprant as well as mechanistic insights into its PK and sensitivity to drug interactions. Liquid chromatography-mass spectrometry/ mass spectrometry was used to measure plasma and urine concentrations. Geometric mean ratios [90\% confidence interval $(\mathrm{CI})]$ for oral fevipiprant with or without cyclosporine were $3.02(2.38,3.82)$ for $C_{\max }, 2.50(2.17,2.88)$ for $A U C_{\text {last }}$, and $2.35(1.99,2.77)$ for $A U C_{\text {inf- }}$ The geometric mean ratios $(90 \% \mathrm{Cl})$ for fevipiprant intravenous microdose with or without cyclosporine were $1.04(0.86,1.25)$ for $C_{\text {max }}, 2.04(1.83,2.28)$ for $A U C_{\text {last }}$, and $1.95(1.76,2.16)$ for $A U C_{\text {inf- }}$ The absolute bioavailability for fevipiprant was approximately 0.3 to 0.4 in the absence and 0.5 in the presence of cyclosporine.
\end{abstract}

The intravenous microdose allowed differentiation between systemic and presystemic effects of cyclosporine on fevipiprant, demonstrating a small (approximately 1.2-fold) presystemic effect of cyclosporine and a larger (approximately twofold) effect on systemic elimination of fevipiprant. Uptake by OATP1B3 appears to be the rate-limiting step in the hepatic elimination of fevipiprant, whereas P-gp does not have a relevant effect on oral absorption.

\section{SIGNIFICANCE STATEMENT}

The drug interaction investigated here with cyclosporine, an inhibitor of several drug transporters, provides a refined quantitative understanding of the role of active transport processes in liver and intestine for the absorption and elimination of fevipiprant as well as the basis to assess the need for dose adjustment in the presence of transporter inhibitors. The applied intravenous microdose approach presents a strategy to maximize learnings from a trial, limit the number and duration of clinical trials, and enhance mechanistic drug-drug interaction understanding.

\section{Introduction}

Fevipiprant (QAW039) is an oral, competitive antagonist of the prostaglandin $\mathrm{D}_{2}$ receptor 2 (previously called chemoattractant receptor-homologous molecule expressed on type 2 helper $\mathrm{T}$ cells) that dissociates slowly from this receptor (Sykes et al., 2016). In phase II trials, fevipiprant significantly decreased sputum eosinophil counts and reduced airway smooth muscle mass in patients with asthma (Erpenbeck et al., 2016a; Gonem et al., 2016; Bateman et al., 2017; Saunders et al., 2019), but phase III results (ClinicalTrials.gov numbers NCT02555683, NCT02563067,

This study was funded by Novartis Pharma AG, Basel, Switzerland.

K.-I.U., V.J.E., W.E., and M.Z. were employees of Novartis at the time the study was being carried out.

https://doi.org/10.1124/dmd.120.090852.

S This article has supplemental material available at dmd.aspetjournals.org.
NCT03215758, NCT03226392) did not support submission in this indication.

One aspect of drug development is to build a detailed understanding of the processes underlying the pharmacokinetics $(\mathrm{PK})$ of the drug to determine if, and to what extent, co-medications or other factors can affect its PK. In this context, regulatory authorities encourage obtaining intravenous PK data of drugs in development (European Medicines Agency, 1987). PK parameters requiring intravenous data (such as absolute bioavailability and systemic clearance) can increase the predictability of physiologically based modeling of PK and are generally important for any quantitative estimation of exposure change with, for example, change in formulation, age, partial inhibition of a clearance pathway by DDIs, or organ impairment.

Renal clearance and hepatic elimination via glucuronidation and/or biliary secretion contribute to the elimination of fevipiprant; intravenous PK data can help to estimate the contributions of these clearance pathways more quantitatively. In a human absorption, distribution, metabolism, and excretion (ADME) study of fevipiprant, the fraction

ABBREVIATIONS: ADME, absorption, distribution, metabolism and excretion; AE, adverse events; AG, acyl-glucuronide; ALT, alanine aminotransferase; $A U C_{\text {inf }}$, area under the plasma concentration-time curve from time zero to infinity; $A U C_{\text {last, area }}$ under the plasma concentration-time curve from time zero to the time of the last quantifiable concentration; $\mathrm{Cl}$, confidence interval; $\mathrm{CL}$, clearance; $\mathrm{CLr}$, renal clearance; ECG, electrocardiogram; F, absolute bioavailability; LC-MS/MS, liquid chromatography-tandem mass spectrometry; LLOQ, lower limits of quantification; $\mathrm{m} / \mathrm{z}$, mass to charge ratio; OATP, organic anion transporting polypeptide; P-gp, P-glycoprotein; PK, pharmacokinetics; $t_{1 / 2}$, terminal half-life; $T_{\max }$, time to reach peak or maximum concentration following drug administration; UGT, uridine $5^{\prime}$-diphospho-glucuronosyltransferase; $V$, volume of distribution; $\mathrm{Vz} / \mathrm{F}$, the apparent volume of distribution during the terminal phase following extravascular administration. 
of the oral dose absorbed from the intestine was estimated to be at least $43.5 \%$ (42.1\% of the total radioactive dose recovered from urine and $1.4 \%$ as metabolites in feces) (Pearson et al., 2017). However, the absolute bioavailability, i.e., the fraction of the oral dose reaching the systemic circulation unchanged, could be higher or lower than this minimal estimate of absorption. In vitro data indicate that fevipiprant is taken up via organic anion transporting polypeptide (OATP) $1 \mathrm{~B} 3$ into the liver, followed by formation of an acyl glucuronide (AG) metabolite by several uridine 5'-diphospho-glucuronosyltransferase (UGT) enzymes. Of note, the AG metabolite is the only major circulating metabolite of fevipiprant and is not pharmacologically active (Pearson et al., 2017). Organic anion transporter 3 is responsible for the active renal excretion of fevipiprant (Pearson et al., 2017). Because fevipiprant is a substrate of P-glycoprotein (P-gp, or multidrug resistance protein 1) and UGT enzymes, intestinal efflux and metabolism could have an impact on its absorption and first-pass metabolism, respectively (Pearson et al., 2017). In addition, the hepatic first-pass extraction by OATP1B3-mediated uptake may influence the bioavailability of fevipiprant.

The aim of this study was to determine the effect of oral cyclosporine, an inhibitor of OATP1B3 (Shitara et al., 2012) and P-gp (Kovarik and Koelle, 1999), on the PK of fevipiprant and also to increase the overall understanding of fevipiprant PK. Cyclosporine has no inhibitory effects on the other elimination pathways of fevipiprant, that is, UGTs [no inhibition was reported at time of survey in the Metabolism and Transport Drug Interaction Database (https://sop.washington.edu/ department-of-pharmaceutics/research/drug-interaction-database/)] and organic anion transporter 3 (El-Sheikh et al., 2013). An intravenous microdose of stable (i.e., nonradioactive) isotope-labeled fevipiprant ( $\left[{ }^{13} \mathrm{C}_{2}^{15} \mathrm{~N}_{2}\right]$ fevipiprant) (Fig. 1) was coadministered with unlabeled oral fevipiprant to determine its absolute bioavailability and systemic clearance, both in the absence and presence of cyclosporine. Labeled and unlabeled fevipiprant are identical biologically, i.e., their interaction with, for example, the target or drug transporters is not expected to differ, but they can be distinguished analytically by mass spectrometry. This allows intravenous and oral data to be obtained on the same drug, from the same study participant, at the same time without the risk of a bias of the intravenous PK data because of the microdose in case of PK nonlinearity (Lappin et al., 2006). In the context of the DDI assessment, this allowed determination of systemic (from fevipiprant intravenous administration) as well as "presystemic plus systemic" (from fevipiprant oral administration) effects of cyclosporine, adding mechanistic granularity.

\section{Materials and Methods}

Study Objectives. The primary objective was to determine the effect of cyclosporine on the following three key PK measures of orally administered

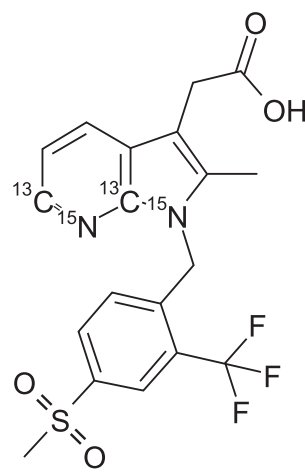

Fig. 1. Structure of fevipiprant showing the positions of the stable isotope-labeling $\left({ }^{13} \mathrm{C}_{2}^{15} \mathrm{~N}_{2}\right)$ used for the intravenous microdosing. fevipiprant in healthy volunteers: 1) the area under the plasma concentration-time curve from time zero to the time of the last quantifiable concentration $\left.\left(\mathrm{AUC}_{\text {last }}\right) ; 2\right)$ the area under the plasma concentration-time curve from time zero to infinity $\left(\mathrm{AUC}_{\mathrm{inf}}\right)$; and 3$)$ the maximum plasma concentration $\left(C_{\max }\right)$.

The secondary objectives were to determine 1$)$ the absolute bioavailability $(\mathrm{F})$ and the absolute disposition parameters of fevipiprant, i.e., clearance (CL) and volume (V) of distribution, by administering an intravenous microdose of stable isotope-labeled fevipiprant concomitantly with the oral dose; 2) the effect of cyclosporine on the PK of the intravenous microdose of fevipiprant (V, CL, $\mathrm{AUC}_{\text {last }}$, and $\left.\mathrm{AUC}_{\mathrm{inf}}\right) ; 3$ ) the safety and tolerability of fevipiprant administered both orally and intravenously, with and without coadministration of cyclosporine; and 4) the effect of cyclosporine on the PK of the major AG metabolite of oral fevipiprant. The study protocol was approved by the Institutional Review Board for the study center, and the study was conducted according to the ethical principles of the Declaration of Helsinki.

Study Design. This was an open-label, single-sequence, two-period, crossover study with two treatment periods separated by a washout period of 7-14 days (Fig. 2). The study was carried out at IQVIA (formerly QuintilesIMS) (Overland Park, KS). The investigational drugs, fevipiprant $150 \mathrm{mg}$ film-coated tablets and fevipiprant $100 \mu \mathrm{g}$ labeled intravenous microdose $\left(\left[{ }^{13} \mathrm{C}_{2}^{15} \mathrm{~N}_{2}\right]\right.$ fevipiprant $)$ (Fig. 1), were prepared and released by Novartis Technical Research and Development. Cyclosporine 100 and 25 mg soft gelatin capsules (Neoral Novartis Pharma AG, Basel, Switzerland) were commercially available and sourced locally by the site.

In Treatment Period 1, study participants were admitted to the clinic on day -1 for baseline evaluations at least 12 hours before dosing. On day 1, they received a single oral dose of fevipiprant $150 \mathrm{mg}$, followed by an intravenous microdose of labeled fevipiprant $(100 \mu \mathrm{g}) 1$ hour ( \pm 5 minutes) later. Participants fasted for 8 hours before the oral dose administration and continued to fast for 2 hours afterward, and they were confined to the clinic for approximately 28 hours following the oral study drug administration, during which time blood and urine samples for PK analysis and safety assessments were taken. On days 3-5, participants returned to the study site for outpatient safety and PK visits. They returned to the clinic for Treatment Period 2 following a washout period; overall, 7-14 days separated day 1 in Treatment Period 1 from nominal day 16 in Treatment Period 2. Anyone that prematurely discontinued from Treatment Period 1 was required to complete an early termination visit (day 15 visit).

In Treatment Period 2, participants were admitted to the clinic on day 15 for baseline evaluations at least 12 hours before dosing. On days 16-19, they received oral doses of cyclosporine $175 \mathrm{mg}$ twice daily, and on day 20, they received a single oral dose of cyclosporine $175 \mathrm{mg}$ in the morning. On day 17, participants received a single oral dose of fevipiprant $150 \mathrm{mg}$ in parallel with the morning cyclosporine dose ( \pm approximately 3 minutes), followed by administration of an intravenous microdose of labeled fevipiprant ( $100 \mu \mathrm{g}) 1$ hour ( \pm 5 minutes) later. On all dosing days, participants fasted for 8 hours before the oral drug administration in the morning and continued to fast for 2 hours thereafter. Samples were taken for PK analysis on days 16-21. Participants fasted for 2 hours before the evening doses of cyclosporine and continued to fast for 1 hour thereafter, and they were confined to the clinic until study day 21 . On day 23 , participants returned to the study site for safety assessments; end of study safety assessments were completed on day 25.

The sample size (16 participants so that at least 12 would complete the study) was selected to control the width of the confidence interval for the geometric mean ratio for fevipiprant $\mathrm{AUC}$ and $C_{\max }$ when given with and without cyclosporine. Further details may be found in the Supplemental Materials.

Key Inclusion and Exclusion Criteria. Men and women were admitted as study participants if they were aged 18-55 years and in good health, as determined by past medical history, physical examination, vital signs, electrocardiogram (ECG), and laboratory tests at screening and/or at first baseline visit. Further details on vital sign measurement are provided in the Supplemental Materials. Participants had to weigh between 60 and $90 \mathrm{~kg}$ and to have a body mass index within the range of $20-30 \mathrm{~kg} / \mathrm{m}^{2}$. Study participants gave written informed consent before any assessment took place, and they had to be able to communicate well with the investigator and to understand and comply with the requirements of the study. Exclusion criteria details are provided in the Supplemental Materials.

Pharmacokinetic Analyses. PK blood and urine samples were taken at prespecified time points from all participants and acidified pending analysis to avoid back-conversion of the AG metabolite to fevipiprant (details are provided in the Supplemental Materials). Validated liquid chromatography-mass 


\begin{tabular}{|c|c|c|c|c|c|c|c|c|c|}
\hline $\begin{array}{c}\text { Days }-21 \\
\text { to }-1\end{array}$ & \begin{tabular}{|c|} 
Day 1 \\
Fevipiprant $150 \mathrm{mg}$ oral \\
+ \\
IV microdose \\
(100 $\mu \mathrm{g}$ dosed one hour \\
after oral fevipiprant)
\end{tabular} & $\begin{array}{l}\text { Days } \\
2 \text { to } 5\end{array}$ & $\begin{array}{l}\text { Days } 6 \text { to } 14 \\
\text { Washout }\end{array}$ & 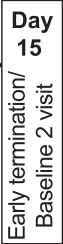 & \begin{tabular}{|c|} 
Day 16 \\
Cyclosporine \\
oral \\
$175 \mathrm{mg}$ bid
\end{tabular} & \begin{tabular}{|c|} 
Day 17 \\
Cyclosporine oral \\
$175 \mathrm{mg}$ bid + \\
fevipiprant $150 \mathrm{mg}$ \\
oral + IV microdose \\
(100 $\mu \mathrm{g}$ dosed one hour \\
after oral fevipiprant)
\end{tabular} & $\mid$\begin{tabular}{||c||} 
Day 18 to 19 \\
Cyclosporine \\
oral \\
$175 \mathrm{mg}$ bid \\
Day 20 \\
Cyclosporine \\
oral \\
$175 \mathrm{mg}$ qd
\end{tabular} & \begin{tabular}{|c|} 
Days \\
21 to \\
24
\end{tabular} & Day 25 \\
\hline $\begin{array}{c}\text { Screening } \\
\text { period }\end{array}$ & \multicolumn{4}{|c|}{ Treatment Period 1} & \multicolumn{4}{|c|}{ Treatment Period 2} & $\begin{array}{l}\text { End of } \\
\text { study }\end{array}$ \\
\hline
\end{tabular}

Fig. 2. Study design.

spectrometry/mass spectrometry (LC-MS/MS) methods were used to measure the plasma concentrations of unlabeled fevipiprant (given orally) and labeled fevipiprant (given as intravenous microdose) using the transitions of mass to charge ratio (m/z) 427 to $\mathrm{m} / \mathrm{z} 145$ and of m/z 431 to $\mathrm{m} / \mathrm{z} 149$, respectively. The MS/MS transition used for the acyl glucuronide metabolite of (unlabeled) fevipiprant was $\mathrm{m} / \mathrm{z} 603$ to $\mathrm{m} / \mathrm{z}$ 427. The MS/MS transition used for the measurement of cyclosporine was $\mathrm{m} / \mathrm{z} 1219.9$ to $\mathrm{m} / \mathrm{z} 1202.9$. Further details of the LC-MS/MS methods may be found in the Supplemental Materials. The plasma concentrations of the AG metabolite of unlabeled fevipiprant and the blood concentrations of cyclosporine were measured by validated LC-MS/MS methods. The concentrations of unlabeled fevipiprant and its major AG metabolite in urine were determined using qualified LC-MS/MS methods. Concentrations below the lower limits of quantification (LLOQ) were reported as "zero," and missing data were labeled as such in the bioanalytical data reports.

The following PK measures of fevipiprant were determined using the actual recorded sampling times and noncompartmental method(s) with Phoenix WinNonlin (Version 6.4): $C_{\max }, T_{\max }$ (time to reach peak or maximum concentration following drug administration), $\mathrm{AUC}_{\text {last }}, \mathrm{AUC}_{\mathrm{inf}}, t_{1 / 2}$ (terminal half-life), $\mathrm{Vz} / \mathrm{F}$ (the apparent volume of distribution during the terminal phase following extravascular administration), $\mathrm{CL}, \mathrm{F}$, and $\mathrm{CL} / \mathrm{F}$ from the plasma concentration time data. For the $\mathrm{AG}$ metabolite, $C_{\max }, T_{\max }, \mathrm{AUC}_{\text {last }}, \mathrm{AUC}_{\text {inf }}$, and $t_{1 / 2}$ were determined using noncompartmental analysis only after oral administration. The amount excreted into the urine of unlabeled fevipiprant and its AG metabolite was determined from the urine concentration and volume-time data. The renal clearance (CLr) of fevipiprant and its AG metabolite was determined as Ae/AUC from the same time period. The absolute oral bioavailability $(\mathrm{F})$ was estimated as a ratio of the dose-normalized AUCs following oral and intravenous administration $\left[\mathrm{F}=\left(\mathrm{AUC}_{\mathrm{po}} * \mathrm{DOSE}_{\mathrm{iv}}\right) /\left(\mathrm{AUC}_{\mathrm{iv}} * \mathrm{DOSE}_{\mathrm{po}}\right)\right]$. The linear trapezoidal rule was used for AUC calculation. Regression analysis of the terminal elimination phase for the determination of $t_{1 / 2}$ included at least three data points after $C_{\max }$. If the adjusted $R^{2}$ (coefficient of determination) value of the regression analysis of the terminal phase was less than 0.75 , no values were reported for $t_{1 / 2}$, $\mathrm{AUC}_{\text {inf }}, \mathrm{CL}, \mathrm{V}$, or CL/F.

Key Safety and Tolerability Assessments. Safety assessments consisted of collecting all adverse events (AEs) and serious AEs with their severity and relationship to study drug. Laboratory evaluations included hematology, biochemistry, and urinalyses. Vital signs, physical condition, body weight, and standard 12-lead ECG were also assessed.

Statistical Analyses. Participants' data were analyzed according to the study treatments received for all analysis sets. The safety analysis set included all participants who received any study drug. The PK analysis set included all participants with at least one available valid PK concentration measurement, who received any study drug and with no protocol deviations that had an impact on PK data. For the primary endpoints, the log-transformed fevipiprant PK measures $\left(\mathrm{AUC}_{\text {last }}, \mathrm{AUC}_{\mathrm{inf}}\right.$, and $C_{\max }$ ) were analyzed separately by a mixed-effects model, with treatment as a fixed effect and participant as random effect. The estimated mean and $90 \%$ confidence interval (CI) for treatment difference (fevipiprant plus cyclosporine vs. fevipiprant alone) were back-transformed to obtain a geometric mean ratio and $90 \%$ CI of the ratio. SAS software was used for all statistical analyses. Statistical analysis of the secondary endpoints is provided in the Supplemental Materials

\section{Results}

Participants. Sixteen participants entered the study, of whom 13 $(81.3 \%)$ completed Treatment Period 1. In total, 14 participants were male and 2 were female; 11 were Caucasian, 4 were black, and 1 of another race (not specified). Their mean age was 32.5 years (range: 20-52) with a mean weight of $77.7 \mathrm{~kg}$ (range: $64.5-88.7$ ) and mean body mass index of $25.6 \mathrm{~kg} / \mathrm{m}^{2}$ (range: $21.6-30.0$ ). Three participants discontinued for the following reasons: because of an $\mathrm{AE}(n=1)$, being lost to follow-up ( $n=1)$, or physician decision (positive drug screen on day $15 ; n=1)$. All 13 participants who completed Treatment Period 1 entered Treatment Period 2 and completed the study. All 16 participants were included in the PK and the safety analysis sets.

Effect of Cyclosporine on the PK of Fevipiprant (Oral and Intravenous Doses). Peak concentrations of oral fevipiprant were seen 1.5 hours after the fevipiprant dose and 3 hours after the cyclosporine plus fevipiprant dose (Fig. 3; Table 1). The mean concentration-time data for fevipiprant with and without cyclosporine are provided in Supplemental Table 1. For $C_{\max }$, the geometric mean ratio $(90 \% \mathrm{CI}$ ) was $3.02(2.38,3.82)$ (Supplemental Table 2), indicating an approximately threefold increase in peak exposure of fevipiprant when coadministered with cyclosporine. The geometric mean ratios $(90 \% \mathrm{CI})$ were 2.50 (2.17, 2.88) for $\mathrm{AUC}_{\text {last }}$ and $2.35(1.99,2.77)$ for $\mathrm{AUC}_{\mathrm{inf}}$ (Supplemental Table 2), indicating that the effect of cyclosporine on fevipiprant total exposure is smaller than the effect on peak exposure. Oral clearance and volume of distribution of fevipiprant were reduced by approximately $50 \%$ upon coadministration with cyclosporine, whereas $t_{1 / 2}$ was similar (Table 1)

$C_{\max }$ values of the fevipiprant intravenous microdose were similar in the presence and absence of cyclosporine (Fig. 4; Table 2), with a geometric mean ratio for $C_{\max }(90 \% \mathrm{CI})$ of $1.04(0.86,1.25)$ (Supplemental Table 4). The mean concentration-time data for the fevipiprant intravenous microdose with and without cyclosporine are provided in Supplemental Table 3. $T_{\max }$ was typically at the first sampling time, i.e., 2 minutes after intravenous dosing. A $t_{1 / 2}$ and $\mathrm{V}$ for fevipiprant are not reported, as the terminal phase was not sufficiently covered in the concentration-time data, which is required to derive $\mathrm{V}$. The $t_{1 / 2}$ after intravenous administration is expected to be identical to that derived from the oral data. $\mathrm{AUC}_{\mathrm{inf}}$ and $\mathrm{CL}$ were estimated by noncompartmental analysis (Table 2) despite the limitations in describing the terminal phase. Because the captured concentration-time profiles cover a 1000-fold range in concentrations, the bias resulting from the incomplete representation of the AUC after concentrations dropped below the LLOQ of $20 \mathrm{pg} / \mathrm{ml}$ is considered to be small. Both $\mathrm{AUC}_{\text {last }}$ and estimated $\mathrm{AUC}_{\text {inf }}$ for fevipiprant intravenous microdose were approximately twofold higher in presence of cyclosporine (Table 2), with geometric mean ratios $(90 \% \mathrm{CI})$ of $2.04(1.83,2.28)$ and 1.95 (1.76, 2.16), respectively (Supplemental Table 4).

Absolute Bioavailability of Fevipiprant. The combination of oral and intravenous microdose fevipiprant PK data were used to estimate its absolute bioavailability. Because of the limitations to deriving $\mathrm{AUC}_{\mathrm{inf}}$ for the intravenous profiles, the absolute oral bioavailability for fevipiprant was based on comparison of dose normalized $\mathrm{AUC}_{\text {last }}$ (mean \pm S.D.) and was $0.43 \pm 0.09$ and $0.53 \pm 0.16$ in the absence and presence of cyclosporine, respectively. These values are expected to be 


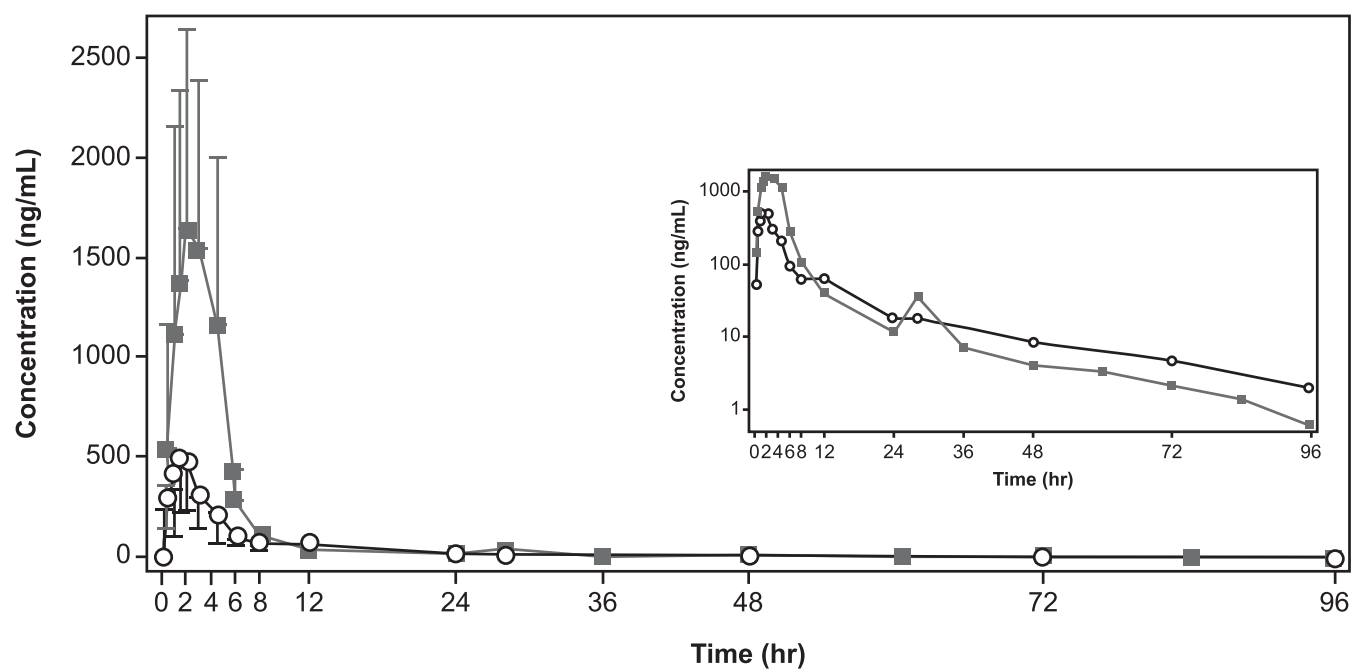

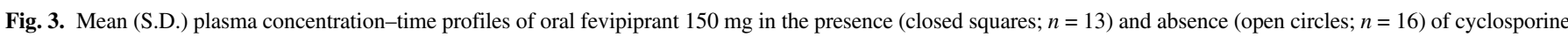
$175 \mathrm{mg}$ twice daily, linear view and semilogarithmic view (inset).

slightly higher than the real values because the covered time interval is longer for the oral data. The absolute bioavailability of fevipiprant was also estimated based on comparison of $\mathrm{AUC}_{0-11 \mathrm{~h}}$ because most intravenous profiles could be measured up to 11 hours postdose. Estimates based on this comparison were (mean \pm S.D.) $0.28 \pm 0.05$ and $0.48 \pm 0.16$ in the absence and presence of cyclosporine, respectively. Using this method, a larger fraction of the fevipiprant oral profile is ignored; therefore, this value is a minimal estimate of the real value, which is expected to be in the range defined by the assessments based on $\mathrm{AUC}_{\text {last }}$ and $\mathrm{AUC}_{0-11} \mathrm{~h}$, i.e., approximately $0.3-0.4$ in the absence and 0.5 in the presence of cyclosporine.

Effect of Cyclosporine on the PK of the Major AG Metabolite of Fevipiprant. No relevant change in exposure of the AG metabolite of oral fevipiprant was seen in the presence of cyclosporine (Table 3 ). Consequently, the metabolite-to-fevipiprant ratio of $\mathrm{AUC}_{\text {last }}$ decreased from 1.5 to 0.59 in presence of cyclosporine. The mean concentration-time data for the AG metabolite with and without cyclosporine are shown in Supplemental Table 1. Geometric mean ratios for $\mathrm{PK}$ measures for the $\mathrm{AG}$ metabolite are shown in Supplemental Table 5.

Effect of Cyclosporine on the Urinary Excretion of Fevipiprant and Its AG Metabolite. Coadministration with cyclosporine did not result in any relevant changes in the renal clearance of oral fevipiprant (Table 1) and its AG metabolite (Table 3). However, consistent with the higher exposure, the fraction of the dose excreted as unchanged fevipiprant into urine within 24 hours increased by 2.5 -fold from $16.7 \% \pm 3.55 \%$ to $40.9 \% \pm 7.50 \%$ when coadministered with cyclosporine. There was only a slight increase in the amount of AG metabolite excreted into urine from $31.7 \pm 6.08$ to $37.3 \pm 4.79 \mathrm{mg}$ in the presence of cyclosporine (corresponding to approximately $15 \%$ or $18 \%$ of the fevipiprant dose).

Effect of Fevipiprant on the PK of Cyclosporine and Concentration-Effect Relationship of Cyclosporine. No relevant change in mean trough blood concentrations of cyclosporine was observed from day 17 in the morning (before administration of fevipiprant) to any time point after fevipiprant administration (mean trough blood concentrations were in the range of $45-54 \mathrm{ng} / \mathrm{ml}$ cyclosporine). This indicates the absence of a major effect of fevipiprant $150 \mathrm{mg}$ on the PK of cyclosporine and that cyclosporine steady state had been achieved at the time of fevipiprant dosing.

The relationship of trough concentrations of cyclosporine to the observed change in oral fevipiprant $C_{\max }$ was explored graphically (Fig. 5). There was no apparent trend for an increasing effect on fevipiprant $C_{\max }$ with increasing trough concentrations of cyclosporine.

Safety and Tolerability. Overall, administration of fevipiprant alone and fevipiprant plus cyclosporine showed no major or novel safety signals. There were 20 AEs reported in nine patients: headache $(n=3)$, nausea $(n=2)$, alanine aminotransferase (ALT) elevation $(n=1)$, back pain $(n=1)$, catheter site hematoma $(n=1)$, contact dermatitis $(n=1)$, dizziness $(n=1)$, dysgeusia $(n=1)$, flushing $(n=1)$, muscle fatigue $(n=1)$, pharyngitis $(n=1)$, upper respiratory tract infection $(n=1)$, chlamydial urethritis $(n=1)$, vessel puncture site pain $(n=1)$, and vomiting $(n=1)$. A breakdown of the safety data by treatment period may be found in the Supplemental Materials (Supplemental Table 6).

TABLE 1

Pharmacokinetic measures for oral fevipiprant with and without coadministration of cyclosporine

Data are arithmetic means \pm S.D. $(\mathrm{CV} \%)[\mathrm{n}] . \mathrm{CV} \%=$ Coefficient of variation $(\%)=$ S.D. $/$ mean*100

\begin{tabular}{|c|c|c|}
\hline Measure (Unit) & Fevipiprant $150 \mathrm{mg}$ Oral, $n=16$ & Cyclosporine $175 \mathrm{mg}$ Twice Daily + Fevipiprant $150 \mathrm{mg}$ Oral, $n=13$ \\
\hline$C_{\max }(\mathrm{ng} / \mathrm{ml})$ & $724 \pm 207(28.5)[n=16]$ & $2270 \pm 809(35.7)[n=13]$ \\
\hline $\mathrm{AUC}_{\text {last }}(\mathrm{h} * \mathrm{ng} / \mathrm{ml})$ & $3210 \pm 601(18.7)[n=16]$ & $8110 \pm 1980(24.4)[n=13]$ \\
\hline $\mathrm{AUC}_{\mathrm{inf}}(\mathrm{h} * \mathrm{ng} / \mathrm{ml})$ & $3330 \pm 718(21.5)[n=15]$ & $7900 \pm 1980(25.1)[n=10]$ \\
\hline$T_{\max }(\mathrm{h})^{a}$ & $1.50(0.50-4.50)[n=16]$ & $3.00(0.92-4.50)[n=13]$ \\
\hline $\mathrm{CL} / \mathrm{F}(1 / \mathrm{h})$ & $47.0 \pm 10.3(22.0)[n=15]$ & $20.2 \pm 5.71(28.2)[n=10]$ \\
\hline $\mathrm{Vz} / \mathrm{F}(1)$ & $1090 \pm 585(53.6)[n=15]$ & $446 \pm 256(57.4)[n=10]$ \\
\hline$t_{1 / 2}(\mathrm{~h})$ & $17.5 \pm 13.5(77.1)[n=15]$ & $14.9 \pm 6.46(43.4)[n=10]$ \\
\hline $\mathrm{CL}_{\mathrm{r}}(\mathrm{l} / \mathrm{h})$ & $9.49 \pm 1.25(13.2)[n=16]$ & $8.45 \pm 2.39(28.3)[n=13]$ \\
\hline
\end{tabular}

${ }^{a}$ For $T_{\max }$, data are median (minimum-maximum) $[n]$. 


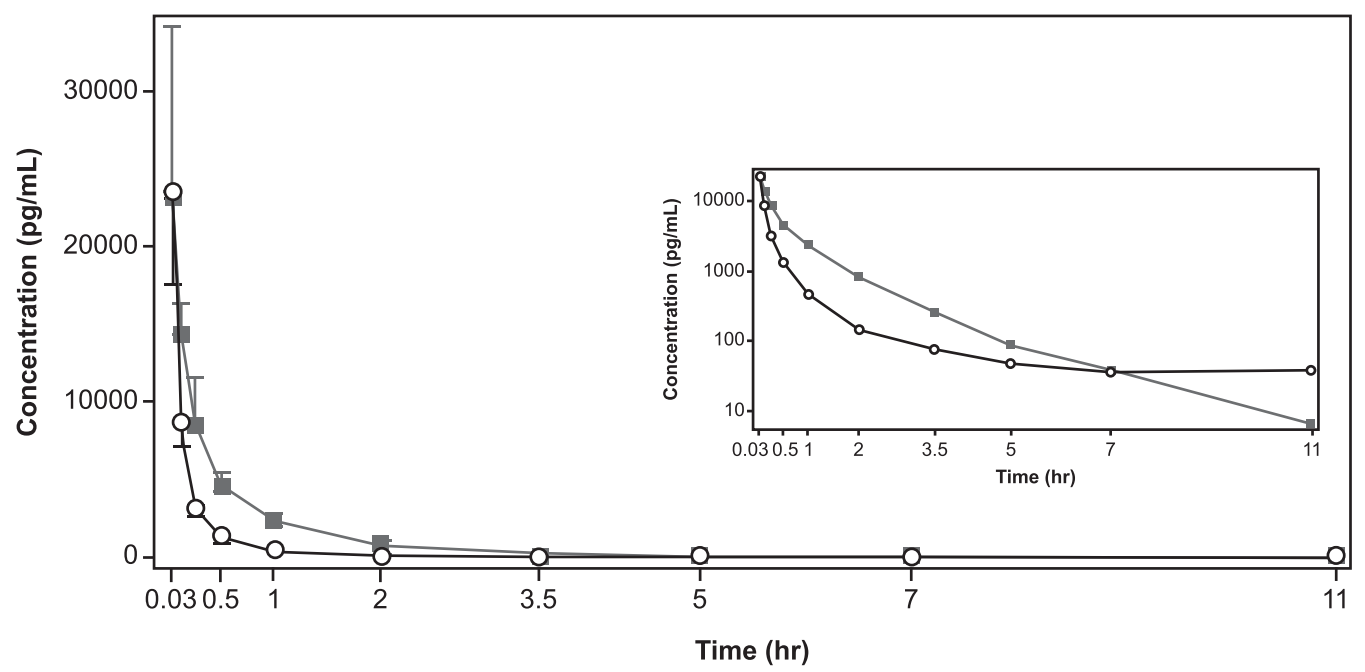

Fig. 4. Mean (S.D.) plasma concentration-time profiles of labeled fevipiprant after intravenous dosing of $100 \mu \mathrm{g}$ in the presence (closed squares; $n=13$ ) and absence (open circles; $n=16$ ) of cyclosporine $175 \mathrm{mg}$ twice daily, linear view and semilogarithmic view (inset).

Ten AEs were suspected to be related to study medication: eight related to cyclosporine, one to fevipiprant (mild postural dizziness), and one to one or other, or both study treatments (mild headache); it was not possible to distinguish which. All reported AEs were of mild intensity except one AE (pharyngitis), which was of moderate intensity. The participant who experienced increased ALT discontinued the study; this AE was not suspected to be related to study drug. Apart from the elevation in ALT in one participant, no clinically significant changes were seen in laboratory parameters, vital signs, or ECG parameters. There were no serious AEs or deaths.

\section{Discussion}

The aim of this study was to assess how cyclosporine, by inhibiting OATP1B3-mediated liver uptake and P-gp-mediated efflux in the intestine and liver, affects the PK of oral fevipiprant. The inclusion of an intravenous microdose of stable isotope-labeled fevipiprant provided major additional learnings without the need for more participants or a longer study duration; the absolute bioavailability of fevipiprant was derived, and the mechanistic DDI understanding increased, by the ability to differentiate between systemic and presystemic effects of cyclosporine. These learnings would be reflected in a potential future fevipiprant drug label in two sections: 1) the absolute bioavailability and dependence on active transport as part of the PK section and 2) the assessment of the need for dose adjustment in presence of OATP1B3 or P-gp inhibitors in the drug interaction section.

In the absence of cyclosporine, the PK properties of fevipiprant, including exposure to its major metabolite, were consistent with earlier studies (Erpenbeck et al., 2016b, 2017; Pearson et al., 2017).
Coadministration of cyclosporine increased the $C_{\max }$ of oral fevipiprant threefold and the $\mathrm{AUC}_{\text {inf }}$ by 2.35 -fold. While fevipiprant concentrations shortly after intravenous dosing were similar, the AUC of intravenousadministered fevipiprant was twofold higher in the presence of cyclosporine, corresponding to a twofold decrease in systemic clearance. The approximately 1.2-fold stronger effect on oral as compared with intravenous exposure $(2.35 / 2$, i.e., $\sim 1.2)$ can be attributed to the effect of cyclosporine on absorption and/or first-pass elimination of fevipiprant. This combined effect was small and indicates that the inhibition of intestinal P-gp has only a minor or no impact. Early clinical investigations in healthy participants indicated a dose-proportional PK of fevipiprant over a twofold dose range (Erpenbeck et al., 2016b), whereas later more comprehensive data in patients demonstrated dose-proportional PK over a 10-fold dose range (unpublished data). Therefore, the magnitude of drug interaction observed here is also relevant for other oral fevipiprant dose levels such as $450 \mathrm{mg}$, which was also tested in patient trials.

Despite the approximate two-fold reduction in clearance, no increase in the terminal half-life of fevipiprant was observed with coadministration of cyclosporine. The likely explanation is a reduced distribution in the presence of cyclosporine, as the terminal half-life depends on the ratio of distribution to clearance. Because cyclosporine reduced CL/F and $\mathrm{Vz} / \mathrm{F}$ to a similar extent, the terminal half-life of fevipiprant remained largely unchanged. Mechanistically, the reduced hepatic uptake caused by inhibition of OATP1B3 can explain the lower volume of distribution of fevipiprant in the presence of cyclosporine. In a rat ADME study with radiolabeled fevipiprant, the liver showed the highest exposure to drug-related radioactivity (unpublished data), suggesting that liver uptake may be a major determinant of the distribution of

TABLE 2

Pharmacokinetic measures for labeled intravenous fevipiprant with and without coadministration of cyclosporine Data are arithmetic means \pm S.D. $(\mathrm{CV} \%)[\mathrm{n}] . \mathrm{CV} \%=$ Coefficient of variation $(\%)=$ S.D. $/$ mean*100.

\begin{tabular}{|c|c|c|}
\hline Measure (Unit) & Fevipiprant $100 \mu \mathrm{g}$ Intravenous, $n=16$ & $\begin{array}{c}\text { Cyclosporine } 175 \mathrm{mg} \text { Twice Daily + Fevipiprant } 100 \mu \mathrm{g} \\
\text { intravenous, } n=13\end{array}$ \\
\hline$C_{\max }(\mathrm{pg} / \mathrm{ml})^{a}$ & $23,600 \pm 6030(25.5)[n=16]$ & $25,000 \pm 8500(34.1)[n=13]$ \\
\hline $\mathrm{AUC}_{\text {last }}(\mathrm{h} * \mathrm{pg} / \mathrm{ml})$ & $5040 \pm 774(15.3)[n=16]$ & $10,300 \pm 2160(20.9)[n=13]$ \\
\hline $\mathrm{AUC}_{\text {inf }}(\mathrm{h} * \mathrm{pg} / \mathrm{ml})$ & $5360 \pm 959$ (17.9) $[n=15]$ & $10,400 \pm 2150(20.7)[n=13]$ \\
\hline CL $(1 / h)$ & $19.2 \pm 3.32(17.3)[n=15]$ & $9.97 \pm 1.97(19.7)[n=13]$ \\
\hline
\end{tabular}

${ }^{a} T_{\max }$ was typically at the first sampling time, i.e., $2 \min (0.033 \mathrm{~h})$ after intravenous dosing. 
TABLE 3

Pharmacokinetic measures for the AG metabolite of fevipiprant (unlabeled, derived from oral fevipiprant) with and without coadministration of cyclosporine

Data are arithmetic means \pm S.D. $(\mathrm{CV} \%)[\mathrm{n}] ; \mathrm{CV} \%=$ Coefficient of variation $(\%)=$ S.D. $/$ mean*100.

\begin{tabular}{|c|c|c|}
\hline Measure (Unit) & Fevipiprant $150 \mathrm{mg}$ Oral, $n=16$ & Cyclosporine $175 \mathrm{mg}$ Twice Daily + Fevipiprant $150 \mathrm{mg}$ Oral, $n=13$ \\
\hline$C_{\max }(\mathrm{ng} / \mathrm{ml})$ & $1180 \pm 333(28.3)[n=16]$ & $1330 \pm 369(27.7)[n=13]$ \\
\hline $\mathrm{AUC}_{\text {last }}(\mathrm{h} * \mathrm{ng} / \mathrm{ml})$ & $6650 \pm 1450(21.8)[n=16]$ & $6720 \pm 1470(21.9)[n=13]$ \\
\hline $\mathrm{M} / \mathrm{P}^{a}$ & 1.5 & 0.59 \\
\hline $\mathrm{AUC}_{\mathrm{inf}}(\mathrm{h} * \mathrm{ng} / \mathrm{ml})$ & $6880 \pm 1580(22.9)[n=16]$ & $6800 \pm 1510(22.3)[n=12]^{b}$ \\
\hline$T_{\max }(\mathrm{h})^{c}$ & $2.0(0.92-6.0)[n=16]$ & $3.0(1.5-4.5)[n=13]$ \\
\hline$t_{1 / 2}(\mathrm{~h})$ & $18.9 \pm 13.0(68.9)[n=16]$ & $13.3 \pm 6.96(52.4)[n=12]^{b}$ \\
\hline $\mathrm{CL}_{\mathrm{r}}$ & $6.07 \pm 1.021 / \mathrm{h}(16.7)[19.4]$ & $6.29 \pm 1.22(19.4)[n=13]$ \\
\hline
\end{tabular}

${ }^{a}$ Molar metabolite-to-parent (M/P) ratio for mean $\mathrm{AUC}_{\text {last }}$ considering the molecular weight difference ( $426 \mathrm{~g} / \mathrm{mol}$ for fevipiprant and $602 \mathrm{~g} / \mathrm{mol}$ for the $\mathrm{AG}$ metabolite).

${ }^{b} \mathrm{AUC}_{\text {inf }}$ and $t_{1 / 2}$ were reported when $R^{2}$ (coefficient of determination in the regression analysis) adjusted value of the terminal elimination phase was $>0.75$.

${ }^{c}$ For $T_{\max }$, data are median (minimum-maximum) $[n]$.

fevipiprant. This change in distribution points to inhibition of liver uptake by OATP1B3 as the predominant mechanism for the effect of cyclosporine.

While in the presence of cyclosporine fevipiprant exposure was increased, little change in exposure to the AG metabolite was observed, and consequently, the metabolite:fevipiprant ratio for AUC $_{\text {last }}$ was decreased 2.5-fold from 1.5 to 0.59 by cyclosporine (Table 3 ). Again, this suggests that reduced uptake into the liver, the major site of fevipiprant glucuronidation, is the primary mechanism of the observed cyclosporine effect. Otherwise, the metabolite: fevipiprant ratio would not decrease so strongly because glucuronidation, as a high-capacity system, is not easily saturated (Williams et al., 2004).

The renal clearance of oral fevipiprant and its AG metabolite were not affected by cyclosporine. However, because of the higher systemic exposure to fevipiprant in the presence of cyclosporine, renal excretion contributed 2.5 -fold more to the elimination of fevipiprant $(40.9 \%$ vs. $16.7 \%$ of the dose excreted into urine).

There was no apparent relationship between the change in oral fevipiprant $C_{\max }$ and trough concentrations of cyclosporine; i.e., within the covered range, higher cyclosporine trough concentrations were not linked to a stronger drug interaction (Fig. 5). Therefore, the degree of drug interaction may not be greater at higher cyclosporine oral doses that provide larger exposures than investigated in this study.

The terminal half-life of the intravenous microdose could not be derived because concentrations dropped below the LLOQ of $20 \mathrm{pg} /$ $\mathrm{ml}$ by 23 hours postdose for most profiles. Concentrations shortly after dosing were approximately 1000-fold above LLOQ, suggesting that most of the AUC of the intravenous microdose was captured (extrapolated fraction of $\mathrm{AUC}_{\mathrm{inf}}$ based on mean data was $\leq 6 \%$, both with and without cyclosporine).

The disposition of transporter substrates such as fevipiprant is complex, making prospective predictions of exposure changes with inhibitors of transporter activity challenging (Poirier et al., 2009a,b; Jamei et al., 2014; Taskar et al., 2020). Part of the challenge is that active transport processes influence absorption, clearance, and tissue distribution, making it difficult to derive clean PK input parameters for modeling from oral data only. Combined intravenous and oral data obtained in this study in the presence and absence of a transporter inhibitor allow differentiation between systemic and presystemic processes and provide more robust parameters. This supports the development of more reliable, physiologically-based PK models. These can be used to predict untested case scenarios, such as transporter DDI effects at steady state, and in the case of fevipiprant, the impact of other OATP1B3 inhibitors on its PK.

There was no effect of fevipiprant $150 \mathrm{mg}$ on the trough concentrations of cyclosporine, which is consistent with expectations based on available drug interaction data for fevipiprant as a perpetrator (Poller et al., 2019). Overall, administration of fevipiprant alone and fevipiprant plus cyclosporine was well tolerated with no unexpected or novel AEs. Most AEs suspected to be drug-related were attributed to cyclosporine. These findings are consistent with previous studies showing that fevipiprant was safe and well tolerated at single and multiple oral doses up to $1800 \mathrm{mg} /$ day (Erpenbeck et al., 2017). The exposure change observed in this study will guide fevipiprant dosing recommendations in presence of OATP1B3 inhibitors in the context of the safety profile of fevipiprant in any potential future drug label.

The addition of a labeled intravenous microdose in this study allowed investigation of the absolute bioavailability and absolute clearance

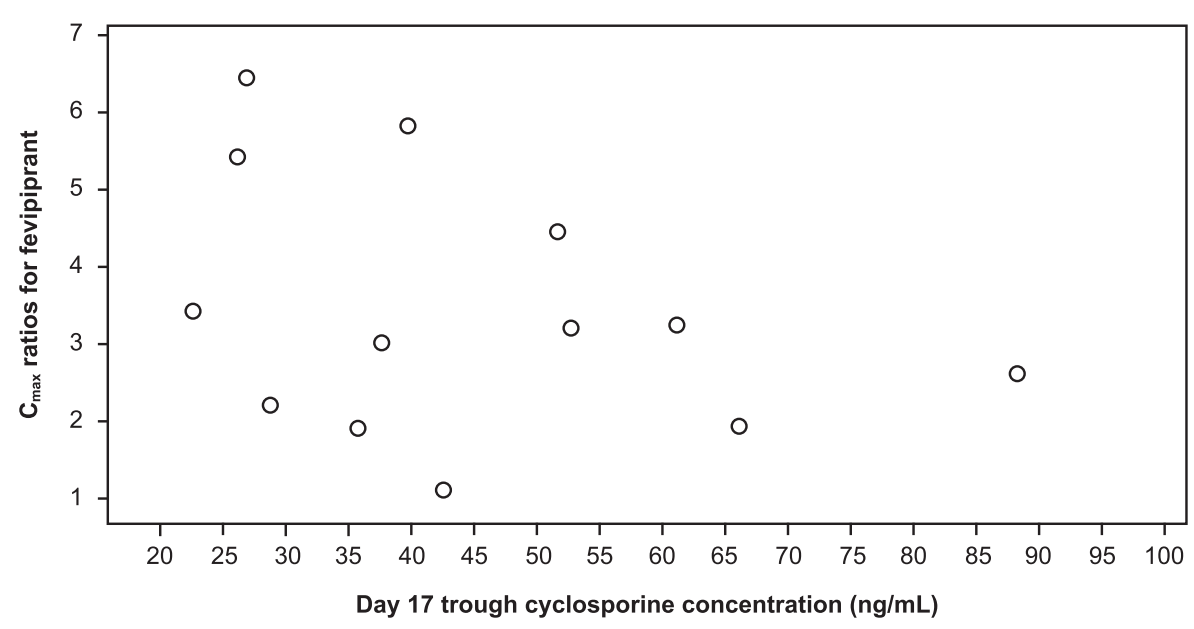

Fig. 5. Scatter plot of oral fevipiprant ratio (Treatment Period 2/Treatment Period 1) for $C_{\max }$ with different cyclosporine concentrations. On the $x$-axis is the trough cyclosporine concentration on day 17 , before the coadministration with fevipiprant. Only study participants with data from both study periods are included. 
without the need to conduct an intravenous toxicology program and a separate intravenous clinical trial. Conventionally, absolute bioavailability studies are crossover studies involving 6-12 participants; the microdose approach negates the need for a separate study with the further advantage that intravenous and oral dose data from the same participants at the same time avoids variability. Furthermore, use of a microdose simplifies formulation work because of the small amounts involved, and there are fewer potential safety concerns.

Concomitant oral dosing of unlabeled and intravenous microdosing of labeled compound in humans has previously been used to determine the absolute bioavailability as well as the oral and intravenous PK of the human immunodeficiency virus protease inhibitor nelfinavir (Sarapa et al., 2005); dabrafenib, a BRAF inhibitor (Denton et al., 2013); saxagliptin, a dipeptidyl peptidase-4 inhibitor; and dapagliflozin, a sodium glucose cotransporter-2 inhibitor (Boulton et al., 2013). In all these studies, the compound given as intravenous microdose was radiolabeled with ${ }^{14} \mathrm{C}$ and quantified by accelerator mass spectrometry. Furthermore, a double tracer technique using oral ${ }^{14} \mathrm{C}$-radiolabeled tofogliflozin simultaneously administered with ${ }^{13} \mathrm{C}$-stable isotope-labeled tofogliflozin has been used successfully in an oral human ADME study to obtain additional information on the intravenous PK of the compound (Schwab et al., 2013). Intravenous microdosing for PK analysis has been accepted as a method by major health authorities (FDA Center for Drug Evaluation and Research, 2012; Boulton et al., 2013).

Administering the microdose after the oral dose circumvents the potential problem of PK nonlinearity at microdose levels (Lappin et al., 2006), as the (labeled) microdose enters the body while the unlabeled compound given orally is present in the therapeutic drug concentration range. We observed little variability in the intravenous microdose data, suggesting good data quality.

Analytical interferences between the unlabeled 1500-fold higher oral dose and the labeled microdose were avoided by careful selection of the positions of labeling (Fig. 1) and the transitions used in the LC-MS/MS analyses. With the MS/MS transitions given in the experimental part, the spillover of the unlabeled compound into the signal of the labeled compound was reduced to only $3 \mathrm{ppm}$ of the unlabeled signal (Gu et al., 2012), which is negligible in the present context. The internal standard used in the LC-MS/MS analyses was fevipiprant labeled with five deuteriums and one ${ }^{13} \mathrm{C}$ in the 4-methanesulfonyl-2-trifluoromethylbenzyl part of the molecule; no interference with the intravenousdosed-labeled fevipiprant is expected.

In this study, a single-sequence design without randomization was used. This is common in DDI studies and accepted by health authorities because the risk for bias of PK endpoints is considered small when investigated drugs do not display changes in clearance with time.

In conclusion, coadministration of cyclosporine increased oral fevipiprant $\mathrm{AUC}_{\mathrm{inf}}$ and $C_{\max }$ by 2.35 - and threefold, respectively. The use of an intravenous microdose allowed estimation of the absolute bioavailability of fevipiprant (0.3-0.4) and differentiation between a small (approximately 1.2-fold) presystemic effect of cyclosporine and a larger (approximately twofold) effect on systemic elimination of fevipiprant. The effect seems to be mainly by inhibition of OATP1B3mediated hepatic uptake of fevipiprant. Additional mechanistic learnings from the intravenous data did not require any extra study participants or a separate trial. Although significant DDI was observed, administration of fevipiprant alone and fevipiprant plus cyclosporine was well tolerated with no novel AEs observed.

\section{Acknowledgments}

Many dedicated scientists have been involved in defining the best labeling strategy as well as a synthesis and release process for the stable isotope-labeled intravenous dose. The authors would like to thank Carsten Bauer, Harry
Tiemessen, Philipp Lustenberger, Valerie Diart, Albrecht Glänzel, Joel Krauser, and Caroline Steib-Lauer for their committed work. In addition, the authors are grateful to Cathy McDonnell (NBS CONEXTS, Dublin, Ireland) for providing medical writing support, which was funded by Novartis Institutes for Biomedical Research, Novartis Pharma AG, Basel, Switzerland, in accordance with Good Publication Practice (GPP3) guidelines (http://www.ismpp.org/gpp3).

\section{Data sharing statement}

Novartis will not provide access to patient-level data if there is a reasonable likelihood that individual patients could be reidentified. Phase 1 studies, by their nature, present a high risk of patient reidentification; therefore, patient individual results for phase 1 studies cannot be shared. In addition, clinical data, in some cases, have been collected subject to contractual or consent provisions that prohibit transfer to third parties. Such restrictions may preclude granting access under these provisions. Where codevelopment agreements or other legal restrictions prevent companies from sharing particular data, companies will work with qualified requestors to provide summary information where possible.

\section{Authorship Contributions}

Participated in research design: Weiss, Erpenbeck, Cain, Vemula, Elbast, Zollinger.

Conducted experiments: Elbast.

Performed data analysis: Weiss, Umehara, Vemula.

Wrote or contributed to the writing of the manuscript: All authors.

\section{References}

Bateman ED, Guerreros AG, Brockhaus F, Holzhauer B, Pethe A, Kay RA, and Townley RG (2017) Fevipiprant, an oral prostaglandin $\mathrm{DP}_{2}$ receptor (CRTh2) antagonist, in allergic asthma uncontrolled on low-dose inhaled corticosteroids. Eur Respir J 50:1-11.

Boulton DW, Kasichayanula S, Keung CF, Arnold ME, Christopher LJ, Xu XS, and Lacreta F (2013) Simultaneous oral therapeutic and intravenous ${ }^{14} \mathrm{C}$-microdoses to determine the absolute oral bioavailability of saxagliptin and dapagliflozin. Br J Clin Pharmacol 75:763-768.

Denton CL, Minthorn E, Carson SW, Young GC, Richards-Peterson LE, Botbyl J, Han C, Morrison RA, Blackman SC, and Ouellet D (2013) Concomitant oral and intravenous pharmacokinetics of dabrafenib, a BRAF inhibitor, in patients with BRAF V600 mutation-positive solid tumors. J Clin Pharmacol 53:955-961.

El-Sheikh AA, Greupink R, Wortelboer HM, van den Heuvel JJ, Schreurs M, Koenderink JB, Masereeuw R, and Russel FG (2013) Interaction of immunosuppressive drugs with human organic anion transporter (OAT) 1 and OAT3, and multidrug resistance-associated protein (MRP) 2 and MRP4. Transl Res 162:398-409.

Erpenbeck V, Cain M, Vemula J, Mandalapu S, Bhuyan R, Rahmanzadeh G, Matsumoto K, Ababa M, and Weiss M (2017) Fevipiprant (QAW039) demonstrates safety, tolerability and consistent PK at high oral doses. Eur Respir J 50:PA4693.

Erpenbeck VJ, Popov TA, Miller D, Weinstein SF, Spector S, Magnusson B, Osuntokun W, Goldsmith P, Weiss M, and Beier J (2016a) The oral CRTh2 antagonist QAW039 (fevipiprant): a phase II study in uncontrolled allergic asthma. Pulm Pharmacol Ther 39:54-63.

Erpenbeck VJ, Vets E, Gheyle L, Osuntokun W, Larbig M, Neelakantham S, Sandham D, Dubois G, Elbast W, Goldsmith P, et al. (2016b) Pharmacokinetics, safety, and tolerability of fevipiprant (QAW039), a novel CRTh2 receptor antagonist: results from 2 randomized, phase 1, placebocontrolled studies in healthy volunteers. Clin Pharmacol Drug Dev 5:306-313.

European Medicines Agency (1987) Pharmacokinetic studies in man. https://www.ema.europa.eu/ en/pharmacokinetic-studies-man

FDA Center for Drug Evaluation and Research (2012) Clinical pharmacology and biopharmaceutics Review(s). https://www.accessdata.fda.gov/drugsatfda_docs/nda/2012/ 202834Orig1s000ClinPharmR.pdf

Gonem S, Berair R, Singapuri A. Hartley R, Laurencin MFM, Bacher G, Holzhauer B, Bourne M, Mistry V, Pavord ID, et al. (2016) Fevipiprant, a prostaglandin D2 receptor 2 antagonist, in patients with persistent eosinophilic asthma: a single-centre, randomised, double-blind, parallelgroup, placebo-controlled trial. Lancet Respir Med 4:699-707.

Gu H, Wang J, Aubry AF, Jiang H, Zeng J, Easter J, Wang JS, Dockens R, Bifano M, Burrell R, et al. (2012) Calculation and mitigation of isotopic interferences in liquid chromatography-mass spectrometry/mass spectrometry assays and its application in supporting microdose absolute bioavailability studies. Anal Chem 84:4844-4850.

Jamei M, Bajot F, Neuhoff S, Barter Z, Yang J, Rostami-Hodjegan A, and Rowland-Yeo K (2014) A mechanistic framework for in vitro-in vivo extrapolation of liver membrane transporters: prediction of drug-drug interaction between rosuvastatin and cyclosporine. Clin Pharmacokinet 53:73-87.

Kovarik JM and Koelle EU (1999) Cyclosporin pharmacokinetics in the elderly. Drugs Aging 15: 197-205.

Lappin G, Rowland M, and Garner RC (2006) The use of isotopes in the determination of absolute bioavailability of drugs in humans. Expert Opin Drug Metab Toxicol 2:419-427.

Pearson D, Weiss HM, Jin Y, Jaap van Lier J, Erpenbeck VJ, Glaenzel U, End P, Woessner R, Eggimann F, and Camenisch G (2017) Absorption, distribution, metabolism, and excretion of the oral prostaglandin D2 receptor 2 antagonist fevipiprant (QAW039) in healthy volunteers and in vitro. Drug Metab Dispos 45:817-825.

Poirier A, Cascais AC, Funk C, and Lavé T (2009a) Prediction of pharmacokinetic profile of valsartan in human based on in vitro uptake transport data. $J$ Pharmacokinet Pharmacodyn 36: 585-611.

Poirier A, Cascais AC, Funk C, and Lavé T (2009b) Prediction of pharmacokinetic profile of valsartan in humans based on in vitro uptake-transport data. Chem Biodivers 6:1975-1987. 
Poller B, Woessner R, Barve A, Tillmann HC, Vemula J, Nica A, Elbast W, Schiller H, End P, Camenisch G, et al. (2019) Fevipiprant has a low risk of influencing co-medication pharmacokinetics: impact on simvastatin and rosuvastatin in different SLCO1B1 genotypes. Pulm Pharmacol Ther 57:101809.

Sarapa N, Hsyu PH, Lappin G, and Garner RC (2005) The application of accelerator mass spectrometry to absolute bioavailability studies in humans: simultaneous administration of an intravenous microdose of $14 \mathrm{C}$-nelfinavir mesylate solution and oral nelfinavir to healthy volunteers. J Clin Pharmacol 45:1198-1205.

Saunders R, Kaul H, Berair R, Gonem S, Singapuri A, Sutcliffe AJ, Chachi L, Biddle MS, Kaur D Bourne $\mathrm{M}$, et al. (2019) $\mathrm{DP}_{2}$ antagonism reduces airway smooth muscle mass in asthma by decreasing eosinophilia and myofibroblast recruitment. Sci Transl Med 11:eaao6451.

Schwab D, Portron A, Backholer Z, Lausecker B, and Kawashima K (2013) A novel double-tracer technique to characterize absorption, distribution, metabolism and excretion (ADME) of [14C] tofogliflozin after oral administration and concomitant intravenous microdose administration of [13C]tofogliflozin in humans. Clin Pharmacokinet 52:463-473.

Shitara Y, Takeuchi K, Nagamatsu Y, Wada S, Sugiyama Y, and Horie T (2012) Long-lasting inhibitory effects of cyclosporin A, but not tacrolimus, on OATP1B1- and OATP1B3-mediated uptake. Drug Metab Pharmacokinet 27:368-378.
Sykes DA, Bradley ME, Riddy DM, Willard E, Reilly J, Miah A, Bauer C, Watson SJ, Sandham DA, Dubois G, et al. (2016) Fevipiprant (QAW039), a slowly dissociating CRTh2 antagonis with the potential for improved clinical efficacy. Mol Pharmacol 89:593-605.

Taskar KS, Pilla Reddy V, Burt H, Posada MM, Varma M, Zheng M, Ullah M, Emami Riedmaier A, Umehara KI, Snoeys J, et al. (2020) Physiologically-based pharmacokinetic models for evaluating membrane transporter mediated drug-drug interactions: current capabilities, case studies, future opportunities, and recommendations. Clin Pharmacol Ther 107:1082-1115.

Williams JA, Hyland R, Jones BC, Smith DA, Hurst S, Goosen TC, Peterkin V, Koup JR, and Ball SE (2004) Drug-drug interactions for UDP-glucuronosyltransferase substrates: a pharmacokinetic explanation for typically observed low exposure (AUCi/AUC) ratios. Drug Metab Dispos 32:1201-1208.

Address correspondence to: $\mathrm{H}$. Markus Weiss, Novartis Institutes for Biomedica Research, Novartis Pharma AG, Basel, Switzerland. E-mail: markus.weiss@ novartis.com 